\title{
B.R. Ambedkar, Partition and the Internationalisation of Untouchability, 1939-1947
}

DOI:

10.1080/00856401.2019.1554618

\section{Document Version}

Accepted author manuscript

Link to publication record in Manchester Research Explorer

\section{Citation for published version (APA):}

Chairez-Garza, J. (2019). B.R. Ambedkar, Partition and the Internationalisation of Untouchability, 1939-1947.

South Asia: Journal of South Asia Studies, 42(1), 80-96. https://doi.org/10.1080/00856401.2019.1554618

\section{Published in:}

South Asia: Journal of South Asia Studies

\section{Citing this paper}

Please note that where the full-text provided on Manchester Research Explorer is the Author Accepted Manuscript or Proof version this may differ from the final Published version. If citing, it is advised that you check and use the publisher's definitive version.

\section{General rights}

Copyright and moral rights for the publications made accessible in the Research Explorer are retained by the authors and/or other copyright owners and it is a condition of accessing publications that users recognise and abide by the legal requirements associated with these rights.

\section{Takedown policy}

If you believe that this document breaches copyright please refer to the University of Manchester's Takedown Procedures [http://man.ac.uk/04Y6Bo] or contact uml.scholarlycommunications@manchester.ac.uk providing relevant details, so we can investigate your claim.

\section{OPEN ACCESS}




\title{
B.R. Ambedkar, Partition and the Internationalisation of Untouchability, 1939-1947
}

Jesús F. Cháirez-Garza

\section{History Department, University of Manchester, Manchester, UK}

jesus.chairez-garza@manchester.ac.uk

\author{
Dr Jesús F. Cháirez-Garza \\ Samuel Alexander Building \\ History Department \\ University of Manchester \\ M13 9PL \\ UK jesus.chairez-garza@manchester.ac.uk
}

\begin{abstract}
This article analyses the way in which B.R. Ambedkar attempted to internationalise the problem of untouchability in the years prior to Partition. The move towards the international was an attempt to secure a political space for Dalits as a consequence of the Muslim League's demand for Pakistan. Unable to reach an agreement with the likes of Gandhi and Jinnah, Ambedkar looked beyond India for support. His plight gained the attention of disparate people including Winston Churchill, Jan Smuts and the members of the Indian Conciliation Group. By exploring these events, this article seeks to rescale the history of untouchability and Partition.
\end{abstract}

Keywords: Ambedkar, Partition, internationalism, Gandhi, Churchill, Smuts, R.R. Bhole, untouchability, United Nations, independence, nationalism 
This paper analyses the way in which B.R. Ambedkar attempted to internationalise the problem of untouchability in the years prior to the Partition of India. ${ }^{1}$ Very few works have paired the question of Dalits, Partition and internationalism for various reasons, including that Partition is not usually thought of as a problem involving Dalits. In the same way, untouchability has not been linked to internationalism because it is usually seen as a regional question with particular regional accents. As well, Partition has usually been seen as a HinduMuslim, and sometimes Sikh, event. Traditional narratives of Partition have tended to focus on the people belonging to these communities, the obstacles they faced and their suffering through the journey of finding a new home. ${ }^{2}$ These types of histories have allowed us to comprehend a difficult topic that was, until very recently, taboo. But, as with most historical works, existing Partition studies provide a skewed vision because the lives and stories of the people who do not fit into the Hindu-Muslim binary have received far less attention. ${ }^{3}$ In particular, the experiences of religious minorities and subaltern communities, including Dalits, have been largely forgotten. As noted by Urvashi Butalia, certain episodes of the multiple histories of Partition remain largely 'untouchable'. ${ }^{4}$

\footnotetext{
${ }^{1}$ Throughout the essay, I use the anachronistic term Dalit. This is the most accepted term to identify such communities. However, my use of this term does not imply the existence of a pan-Indian Dalit community in the years before Partition. Generally, the category 'Depressed Classes' was used before 1935 by the colonial government. After 1935 the term 'Scheduled Castes' was and continues to be used for official business. The term Untouchable was in use throughout the twentieth century. The name 'Harijans' was used mainly by people associated with the nationalist movement led by Congress.

${ }^{2}$ For a survey of the main debates on Partition and caste, see Dwaipayan Sen, 'Caste, Politics and Partition in South Asian History', in History Compass, Vol. 10 (2012), pp. 512-22.

${ }^{3}$ Ravinder Kaur, 'Narrative Absence: An "Untouchable" Account of Partition Migration', in Contributions to Indian Sociology, Vol. 42 (2008), pp. 281-306.

${ }^{4}$ Urvashi Butalia, The Other Side of Silence: Voices from the Partition of India (New Delhi: Viking, 1998), p. 223. See also Priya Kumar and Rita Kothari, 'Sindh, 1947 and Beyond', in South Asia: Journal of South Asian Studies, Vol. 39, no. 4 (2016), pp. 773-89; Nandita Bhavnani, 'Unwanted Refugees: Sindhi Hindus in India and Muhajirs in Sindh', in South Asia: Journal of South Asian Studies, Vol. 39, no. 4 (2016), pp. 790-804; and Rita Kothari and Jasbirkaur Thadani, 'Sindhi Sikhs in India: The Missing People', in South Asia: Journal of South Asian Studies, Vol. 39, no. 4 (2016), pp. 873-90.
} 
Acknowledging Butalia's observation, scholars such as Ravinder Kaur, Gyanendra Pandey, Sekhar Bandyopadhyay, Ram Rawat and Dwaipayan Sen have produced interesting perspectives on Dalit history in the years before and after Partition. Kaur and Pandey have challenged the notion that Dalits were unaffected by the effects of 1947 . Both of them have documented the experiences of violence and displacement suffered by Dalit communities, particularly in Punjab and Delhi. ${ }^{5}$ Bandyopadhyay, Rawat and Sen have each focused on the changes in Dalit politics before 1947, analysing the interactions between the Scheduled Castes Federation (SFC) and Congress, particularly in Bengal and United Provinces. ${ }^{6}$ While Bandyopadhyay argues, based on the 1945-46 elections, that Congress became the main political Dalit party in India in the years prior to Independence, Rawat and Sen argue for a more complex understanding. They show how the Indian political (and electoral) system was tilted against movements for Dalit political autonomy, and in particular, against Ambedkar and the SCF. These works have highlighted many of the tensions present in the traditional narratives of Partition, but they still do not challenge the regional specificity of Partition or the way it shaped Indian politics on a larger level. As a way of complementing the history of the Dalit movement in this period, I look at Ambedkar's efforts to internationalise untouchability and the Dalit cause. This is important because the Dalit problem raised crucial questions concerning the way the international system was shaping itself at this time, especially regarding issues such as minority rights and self-determination.

\footnotetext{
${ }^{5}$ Ravinder Kaur, Since 1947: Partition Narratives among Punjabi Migrants of Delhi (New Delhi: Oxford University Press, 2007); and Gyanendra Pandey, 'Nobody's People: The Dalits of Punjab in the Forced Removal of 1947', in Richard Bessel and Claudia B. Haake (eds), Removing Peoples: Forced Removal in the Modern World (Oxford: Oxford University Press, 2009), pp. 297-319.

${ }^{6}$ The work of Sekhar Bandyopadhyay is the most detailed regarding this period. I have discussed his work in depth in Jesús F. Cháirez-Garza, "Bound Hand and Foot and Handed Over to the Caste Hindus": Ambedkar, Untouchability and the Politics of Partition', in Indian Economic \& Social History Review, Vol 55 (2018), pp. 1-28. See Sekhar Bandyopadhyay, 'Transfer of Power and the Crisis of Dalit Politics in India, 1945-47', in Modern Asian Studies, Vol. 34 (2000), pp. 893-942; Ramnarayan Rawat, 'Making Claims for Power: A New Agenda for Dalit Politics in Uttar Pradesh, 1946-48', in Modern Asian Studies, Vol. 37 (2003), pp. 585-612; and Dwaipayan Sen, 'No Matter How, Jogendranath had to be Defeated: The Scheduled Castes Federation and the Making of Partition in Bengal, 1945-1947', in Indian Economic \& Social History Review, Vol. 49 (2012), pp. 321-64.
} 
Linking the history of untouchability and Partition to internationalism is paramount to unearthing new perspectives about this period. As noted by Hodder, Legg and Heffernan, internationalism has been recently re-conceptualised as 'the most urgent scale at which governance, political activity and resistance must operate when confronting the larger environmental, economic, and strategic challenges of the twenty-first century' ${ }^{7}$ They have also suggested the importance of exploring internationalism as a form of political consciousness and studying the international as a scale of political action. Following their lead, this article re-scales the history of untouchability and Partition towards the international, so shedding light on the efforts of Ambedkar and his successive political parties to find an international political space for Dalits to voice their struggle. This exercise not only informs us of the different scales studies of Partition may take, it also points to the diverse spaces in which the history of untouchability may be located. Connecting Partition, untouchability and the international will elucidate the mechanics of the international system in relation to subaltern political communities. I also explore the way in which certain topics, such as untouchability, were accepted by international players interested in the legacy of imperialism such as former British Prime Minister Winston Churchill and the South African Prime Minister at the time, Jan Smuts. Simultaneously, figures such as Clement Attlee and important Indian nationalists such as Gandhi and Nehru discarded the notion of minority rights in favour of the idea of self-determination and independence. For them, the question of untouchability was not seen as a problem of international magnitude and was rejected very quickly despite Ambedkar's efforts.

I argue that Ambedkar's move towards the international was an attempt to secure a political space for Dalits as a consequence of the Muslim League's demand for Pakistan through the Lahore Resolution. After the Resolution, the possibilities for establishing a united

\footnotetext{
7 Jake Hodder, Stephen Legg and Mike Heffernan, 'Introduction: Historical Geographies of Internationalism, 1900-1950', in Political Geography, Vol. 49 (2015), p. 2.
} 
minority front against Congress began to fade. Ambedkar realised that without a strong Muslim political presence in India, Dalits would be left at the mercy of the Hindu majority. More importantly, if the demand for Pakistan materialised, the political space provided for Dalits by the colonial government, in which Ambedkar had been quite active since the 1920s, would disappear. To avoid this outcome, Ambedkar decided to internationalise the struggle against untouchability, first through the Independent Labour Party of India (ILP) and later via the SCF, as a way to secure electoral and constitutional rights for Dalits. Unable to reach an agreement with Gandhi, Jinnah or Nehru, Ambedkar and his followers looked beyond India for support.

I trace the Dalit move towards the international in three different ways. First, I analyse some of the works produced by Ambedkar in reaction to World War II and the proposal for Pakistan. I then look at Ambedkar's efforts to delay Independence in reaction to the Cabinet Mission of 1946. Ambedkar approached a group of disparate people including Winston Churchill, Jan Smuts and the members of the Indian Conciliation Group for help. He also planned to send a delegation to the United Nations (UN) to present the plight of Dalits to the world. Third, the article looks at the clash between Ambedkar and Gandhi in 1946. This feud saw Gandhi sabotaging Ambedkar's efforts to find international allies. In sum, this article shows how the Muslim's demand for Pakistan elicited a movement towards the international from Ambedkar and his followers to protect India's Dalits.

\section{Reaching a wider audience: Nazis, Empire and Untouchables}

Faisal Devji has recently highlighted the entanglement of various Indian political communities in the years prior to Partition. He follows the interactions between Jinnah, Gandhi, Periyar and Ambedkar, ${ }^{8}$ and suggests that the politics of these men and their

\footnotetext{
${ }^{8}$ Faisal Devji, Muslim Zion: Pakistan as a Political Idea (London: Hurst, 2013), pp. 163-200.
} 
followers should be studied as a whole rather than as separate elements. Devji's overarching argument is that the history of Indian politics was rarely only two-dimensional; rather, it was usually multi-dimensional. The political calculations and decisions made by Hindus, for instance, affected their Muslim, Christian and Dalit counterparts. The communities shared a political space and often worked together to win common political objectives. ${ }^{9}$ Due to such interconnectedness, an event of the magnitude of the demand for Pakistan caused a strong reconfiguration of Indian politics as a whole, not just Muslim politics.

The Lahore Resolution of 1940, combined with developments in the Second World War (WWII), caused a restructuring of Indian political space. Ambedkar reacted to these changes by drawing international attention to untouchability through a series of writings largely directed to a non-Indian audience. One such instance was the publication of his book Thoughts on Pakistan (1940), which he wrote as a reply to the Lahore Resolution from the Independent Labour Party of India, presided over by him. In Thoughts on Pakistan, Ambedkar supported the creation of the new state of Pakistan, arguing that according to the principles of self-determination, Muslims should be permitted their demand. But his support was short-lived. In Pakistan or the Partition of India (1945, 1946), a revised version of Thoughts on Pakistan, Ambedkar was instead in favour of a united India. ${ }^{10}$ This change in attitude was due to Jinnah's demands for Muslim political parity vis-a-vis Hindus at the time of the Cripps Mission in 1942. ${ }^{11}$ Jinnah's move for parity was particularly troublesome for

\footnotetext{
${ }^{9}$ Some examples of the connections between Dalit and Muslim politics are the Aga Khan's 1906 letter advising the colonial government to not classify Dalits as Hindus in the census; the efforts to persuade Dalits to abandon Hinduism for Islam; Choudhry Rahmat Ali's imagining of 'Akhootistan'; and the famous 'Day of Deliverance' which united leaders such as Jinnah, Ambedkar and Periyar.

${ }^{10}$ B.R. Ambedkar, Pakistan or the Partition of India, in Vasant Moon (ed.), Dr. Babasaheb Ambedkar Writings and Speeches, Vol. 8 (New Delhi: Dr. Ambedkar Foundation, [1946] 2014).

${ }^{11}$ The Cripps Mission tried to ensure the loyalty of India to Britain during WWII. It offered the creation of a Constituent Assembly, dominion status and elections after the war. See Nicholas Mansergh, 'The Cripps Mission to India, March-April 1942', in International Journal, Vol. 26 (1971), pp. 338-46; and Auriol Weigold and Ian Copland, 'Louis Fischer and Edgar Snow: Roosevelt's Emissaries in India, 1943', in South Asia: Journal of South Asian Studies, Vol. 35, no. 3 (2012), pp. 709-25.
} 
Ambedkar because it eliminated any possibility of a future Dalit-Muslim alliance, and reimagined the space of Indian politics without a Dalit presence. In reaction to Jinnah's demands, Ambedkar too shifted his position away from the importance of self-determination towards the primacy of minority rights on an international scale. ${ }^{12}$

Ambedkar saw Jinnah's demands to the Cripps Mission as a betrayal of Dalits' political interests and so decided to find support elsewhere. Appealing to the international climate of the early 1940s, Ambedkar linked the history and future of Dalits with the political events taking place in Europe. His speech for the Broadcast Talk from the Bombay Radio Station is a good example. He presented his talk on 9 November 1942, just a few months after the launch of the Quit India movement through which Congress protested against India's involvement in the war. Ambedkar's talk was entitled 'Why Indian Labour is Determined to Win this War'. Later circulated as a pamphlet in Delhi and London, it explained why labour in India supported the British war effort. ${ }^{13}$ Ambedkar's main argument was that by supporting the Allies, Indian labour was fighting for a 'New Order' that could 'save humanity from destruction'. ${ }^{14} \mathrm{He}$ warned the Indian, regardless of 'his religion, his caste and his political faith', about the dangers of supporting the 'Nazi Order' because of the Nazi's 'creed of racial gradation' which regarded 'the German Race as the Race of Supermen', and 'the Brown-Races — and Indians are included in this category__...[are in] the last place in the gradation. As though this is not humiliating enough, the Nazis have declared that the Brown Races shall be the serfs of the German and the White Races'. In short,

\footnotetext{
${ }^{12}$ For a different approach, but quite insightful into Ambedkar's struggle for minority rights, see Anupama Rao, The Caste Question: Dalits and the Politics of Modern India (Berkeley: University of California Press, 2009), Chap. 3.

${ }^{13}$ Although the SCF was founded in July 1942, the 'labour' language used by Ambedkar in this talk shows that he was still unsure what his new political party would look like. B.R. Ambedkar, 'Why Indian Labour is Determined to Win this War' (Delhi: Delhi Printing Works, 1942). The pamphlet is located in R.R. Bhole Papers, Printed Material, No. 5, Nehru Memorial Museum and Library (hereafter NMML), New Delhi.

${ }^{14}$ Ibid., p. 2.
} 
Ambedkar believed that a Nazi victory would pose a 'direct menace to the liberty and freedom of Indians'. ${ }^{15}$

Ambedkar was aware that his support for the war effort might be interpreted as antinationalist and detrimental to the struggle for independence. In an effort to deny these interpretations, Ambedkar highlighted some of the problems of making a fetish of nationalism. He considered that India needed deep political and social change; getting rid of British rule was not enough. He was particularly uncomfortable with notions of nationalism that associated it with 'worship of the ancient past - the discarding of everything that is not local in origin and colour'. ${ }^{16}$ Labour, he said, 'cannot allow the living faith of the dead to become the dead faith of living. Labour will not allow the ever expanding spirit of man to be strangled by the hand of the past which has no meaning for the present and no hope for the future; nor will it allow it to be cramped in a narrow jacket of local particularism'. ${ }^{17}$ If nationalism went unchallenged, India would just be replacing imperialism with the caste system, because 'external independence is quite compatible with internal slavery' ${ }^{18}$ For him, independence only meant that a nation had the liberty to choose its form of government without foreign intervention, but this was not valuable in itself. Rather, the worth of independence depended 'upon the kind of Government and the kind of society that is built up' ${ }^{19}$ According to Ambedkar, an unchallenged vision of nationalism and independence was futile as they did not address the main problems of Indian society, such as caste inequality. Ambedkar suggested that nationalists' efforts should emphasise a campaign for a 'New India' rather than 'Quit India'. His statement is quite revealing; by downplaying the importance of

\footnotetext{
${ }^{15}$ Ibid., pp. 2-4.

${ }^{16} \mathrm{Ibid}$., p. 6.

${ }^{17}$ Ibid.

${ }^{18}$ Ibid., p. 7.

${ }^{19}$ Ibid., pp. 6-7.
} 
nationalism and independence, Ambedkar was criticising the Indian vision of selfdetermination in order to build his defence of minority and human rights.

For Ambedkar, internationalism was the answer for India's inequality. He saw nationalism only as a means to an end. His real interest was to internationalise India's political problems, including untouchability, and he knew that without international collaboration his cause could be easily defeated and Dalits would be without a political space to claim as their own. As Samuel Moyn has shown recently, the rise of human rights discourse in the international arena after WWII, was, paradoxically, the imperialists' answer to the demands for self-determination coming from their colonies. By claiming that all humans were equal, imperial powers were able to deny independence to their colonies arguing that certain countries would not be able to provide human rights to all of their populations. Furthermore, through organisations such as the UN, the imperial powers also retained the right to intervene in the politics of countries in which they deemed human rights could be in danger. ${ }^{20}$ Aware of the tensions between the ideology of self-determination and minority rights, whether it was the Indian or Pakistani imaginary, Ambedkar hinted at possible avenues for interventionism. For him, India needed to be open to ideas from abroad in order to 'repair, transform and recreate the body politic. If nationalism stands in the way of his re-building and re-shaping of life, then Labour must deny nationalism'. ${ }^{21}$ Ambedkar emphatically stated: 'Labour's creed is internationalism. Labour is only interested in nationalism because the wheels of democracy-such as representative Parliaments, responsible Executive, constitutional conventions, etc.,- -work better in a community united

\footnotetext{
${ }^{20}$ Samuel Moyn, The Last Utopia: Human Rights in History (Cambridge, MA/London: Harvard University Press, 2010), esp. Chap. 3. See also Mark Mazower, No Enchanted Place: The End of Empire and the Ideological Origins of the United Nations (Princeton: Princeton University Press, 2013).

${ }^{21}$ Ambedkar, 'Why Indian Labour is Determined to Win this War', p. 7.
} 
by national sentiments'. ${ }^{22}$ Thus, by announcing his belief in internationalism, Ambedkar was preparing a lifeline for Dalit politics in the event of Partition.

Ambedkar's support for internationalism was not entirely uncritical. He wrote:

Labour is aware that, if this is a war against the New Nazi Order, it is not a war for the Old Order. It is a war on both the Old Order as well as the Nazi Order. Labour is aware that the only compensation for the cost of this war is the establishment of a New Order in which liberty, equality and fraternity, will not be mere slogans but will become facts of life.... Without success in the war there can be no self-government and self-determination for India. Without victory in the war, independence will be an idle twaddle. This is the reason why Labour is determined to win this war. ${ }^{23}$

For Ambedkar, WWII was different from other conflicts because it went beyond division of the world's lands. It was instead a clash of 'ideologies relating to the forms and systems of Government under which humanity is to live'. Victory could not be achieved by marching on a country's capital and then dictating the form peace would take. It was a revolution that demanded 'a fundamental change in the terms of associated life between man and man and between nation and nation. It is a revolution which calls for a revision of the terms of associated life - a re-planning of society'. Thus it was the duty of Indian Labour to establish such a New Order to ensure that the world became 'safe for democracy'. ${ }^{24}$

In sum, Ambedkar wanted to internationalise untouchability and the Dalit political space by establishing that Dalits supported the Allied war effort. He rejected any type of social or racial gradation whether in India or abroad, and he opposed imperialism. He hoped that victory over the Nazis would create a New Order in which people and nations across the world would be equal and free.

Ambedkar was not alone in the efforts to internationalise untouchability. Rajaram (R.R.) Bhole (1913-93), one of Ambedkar's main lieutenants, was doing the same. Like Ambedkar, Bhole too was a highly-educated Dalit. He was the first Scheduled Caste member to become a judge of the High Court of Bombay. Recognising his potential, Ambedkar

\footnotetext{
22 Ibid., emphasis added.

${ }^{23}$ Ibid., pp. 8-9.

${ }^{24}$ Ibid., p. 9.
} 
selected Bhole to contest the 1937 elections on the Independent Labour Party ticket. Bhole won the seat of Pune (West) and became an active member of the Bombay Legislative Assembly. ${ }^{25}$ I cannot delve extensively into Bhole's life here, but his work shows that the internationalisation of untouchability was a concerted effort rather than a solo mission undertook by Ambedkar.

Bhole's desire to internationalise untouchability can be appreciated through his pamphlet entitled 'An Untouchable Speaks: The Truth about India Today' ${ }^{26}$ Bhole wanted to 'draw a picture of India as an untouchable sees it' ${ }^{27}$ The pamphlet was written in London around 1944 and was directed at a British audience. It was distributed by the Brittain Publishing Company and had a 'Foreword' by Sir Alfred Watson, the editor of Calcutta's Statesman newspaper. Bhole's purpose was to raise international awareness about untouchability, 'a problem which stirs the heart and conscience of the whole world'. ${ }^{28}$ Similarly to Ambedkar, Bhole emphasised the question of Dalit rights over the efforts for Indian independence.

Bhole began his essay by establishing Dalits' loyalty towards Britain. He claimed that, unlike Indian nationalists, Dalits had remained faithful to Britain over the years. Despite this, the British catered to the interests and interests of the Hindus over those of the Dalits. Bhole gave as an example Dalits' participation in colonial conquests in India. For instance, at the battle of Koregaon in 1818, the East India Company used Dalit (Mahar) soldiers to defeat the Mahrattas. But such help had not been appreciated. Bhole accused the British of abandoning Dalits by ending their recruitment in 1892, having declared them a 'non-martial' people. The same thing had occurred during WWI. Bhole noted that "this "non-martial" class became

${ }^{25}$ I cannot delve extensively into Bhole's life here, but his work shows that the internationalisation of untouchability was a group effort rather than a solo mission.

${ }^{26}$ R.R. Bhole, 'An Untouchable Speaks' (London: Brittain Publishing Company, n.d.). The pamphlet is located in R.R. Bhole Papers, Speeches and Writings, No. 4, NMML.

${ }^{27}$ Ibid.

${ }^{28}$ Ibid., cover. 
"martial"...only to be disbanded after the victory'. ${ }^{29}$ Something similar was happening in WWII in which 'thousands of these scheduled castes are fighting to-day for the cause of freedom' ${ }^{30}$ Bhole found the British attitude perplexing. He also accused the colonial power of denying education to Dalits because it was 'unwilling to interfere with traditional prejudices in a summary manner'. ${ }^{31}$ Furthermore, he considered that the constitutional changes designed by the Cripps Mission gave a great deal of power to Congress. Bhole considered this another betrayal by the British because Congress did not represent Dalits' interests.

The attitude of Congress towards other political groups in India was an important element of Bhole's pamphlet. He considered that Congress did not stand for democracy because its leaders did not want to share power with other groups. Referring to Congress rule after the 1937 provincial elections, Bhole suggested that for this party democracy meant the 'suppression of the liberty of the press, curtailment of civil liberties of the people, and ruthlessly silencing all opposition'. ${ }^{32}$ Like Ambedkar, Bhole compared Congress with the fascist regimes in Europe: 'Congress and the Congress Governments believe in annihilating all parties and making the Congress the only party in the land as is the case in Fascist and Nazi regimes - a result which would be a death blow to Democracy...Congressmen cannot bear rivals and cannot bear sharing credit'.$^{33}$ Bhole made a blunt assessment:

The Untouchables (scheduled castes), who are the third largest group in India, have no funds at their disposal and no Press to speak of. When they demand their freedom they are misrepresented as Communal and anti-national! And the tragic part is that the friends of Hindus and Congress in Great Britain support the Congress Party without examining whether it is the side which they should justly uphold. Whether what is sought is freedom for all or power for some to rule all is the vital question. Will it be a freedom of traditional Hindu India suppressing the scheduled castes, according to tradition? This is the pertinent question. ${ }^{34}$

\footnotetext{
${ }^{29}$ Ibid., p. 16.

30 Ibid.

${ }^{31}$ Ibid.

${ }^{32}$ Ibid., p. 9.

${ }^{33}$ Ibid., p. 10.

${ }^{34}$ Ibid., p. 11.
} 
Despite his strong criticism of the British, Bhole was aware that Dalits needed help from abroad. Displaying his desire to reach an international audience, Bhole argued that 'the Hindu is more alien to a scheduled caste than an Englishman'; but at least 'the Englishman is neutral'. By contrast, 'the Hindu is partial to his own caste and so hostile to a scheduled caste...the caste Hindus are not ashamed to practise the worst crimes against the Untouchables'.$^{35}$ In short, if there was a real cause for freedom in India, it was that of Dalits.

Finally, Bhole reflected on the way the demand for Pakistan disrupted the balance of Indian politics, which mostly affected the alliances between minorities. Following Ambedkar's views, Bhole argued that before the Lahore Resolution, 'the Muslims considered themselves a strong minority. They co-operated with other minorities, e.g., the Untouchables, believing in the adage "Unity is Strength"”. But after the demand for a separate Muslim state, Muslims began to think of themselves as a nation and asked for political parity with the Hindus. Such an attitude 'affected the claims and rights of the Untouchables'. As a consequence, Dalits needed to reach beyond India for help. They would also have to learn to rely on themselves. In particular, Bhole stated that Dalits trusted Dr. Ambedkar, who was 'infusing life into them'. Since Bhole's pamphlet was intended to reach an international audience, his acknowledgement of Ambedkar as the main leader of Dalits was a necessary statement. In his conclusion, Bhole pleaded once again for foreign help. He wrote: 'if there are people anywhere who need the support of the freedom-loving nations and parties, it is undoubtedly the Untouchables of India'. ${ }^{36}$ In short, Bhole wanted his readers to think of untouchability as a problem of rights with international dimensions.

In sum, Ambedkar's and Bhole's writings juxtaposed the history of Dalits and WWII as a way of internationalising untouchability. They aimed to find a political space in which

\footnotetext{
${ }^{35}$ Ibid., p. 13.

${ }^{36}$ Ibid., p. 17.
} 
Dalits could make their voices heard. This was a reaction to the Lahore Resolution and the expansion of the nationalist movement, which were reducing the voices of those who did not fit nicely into the Hindu-Muslim binary. While it is difficult to assess the overall impact of the writings of Bhole and Ambedkar, they did gain them some supporters in Britain, particularly during 1946 when Indian independence began to look as an actual possibility.

\section{The Cabinet Mission, Ambedkar and Churchill}

Ambedkar's attempts to internationalise untouchability were not restricted to the publication of books. He decided to intensify his struggle after the proposals of the Cabinet Mission were published on 16 June $1946,{ }^{37}$ which he saw as a reversal of Britain's earlier position on Dalits. The biggest change was the refusal of the Cabinet Mission to recognise Dalits as an independent political group despite Lord Wavell having acknowledged them as a 'distinct and important element in the National life of India ${ }^{38}$ during the Simla Conference just a year before. The Wavell Plan had prescribed that in future Indian cabinets at least two out of the fourteen seats should be reserved for Dalit politicians nominated by the SCF. However the Cabinet Mission statement did not mention Dalits at all; in fact Ambedkar's party had not even been invited to discuss the proposals. As well, the Executive Council designed by the Cabinet Mission did not include any places for Dalits. Although eventually one seat was conceded to them, the Cabinet Mission gave Congress, and not the SCF, the power to nominate the Scheduled Castes representatives in the interim government.

Ambedkar forcefully rejected these changes. He sent a letter to British prime minister Clement Attlee, describing the proposals as detrimental to the Dalits' position. Ambedkar told

\footnotetext{
${ }^{37}$ For a recent perspective on the Cabinet Mission, see Amar Sohal, 'Ideas of Parity: Muslims, Sikhs and the 1946 Cabinet Mission Plan', in South Asia: Journal of South Asian Studies (2017) [doi: 10.1080/00856401.2017.1367084, accessed 13 November 2017].

${ }^{38}$ B.R. Ambedkar to Clement Attlee, 1 July 1946, Churchill Papers (hereafter CHUR), Public and Political: General: Political: Correspondence and Papers on India, March 1946-December 1946 (hereafter Papers on India), CHUR 2/42A-B, f 132, Churchill Archives (hereafter CHAR), Cambridge.
} 
Attlee that 'as a result of the reduction of status which they have suffered at the hands of the [Cabinet] Mission, the Untouchables are covered with a sense of gloom for their future and are overtaken by fear that they will again be the slaves of the Hindus'. ${ }^{39}$ Ambedkar had three main demands for Attlee: first, he wanted Dalits to be recognised as a political minority in their own right, just as Muslims and Sikhs were; second, he demanded the provision of constitutional safeguards for Dalits; and third, he demanded that at least two representatives of the SCF should be included in the interim government. However Attlee dismissed the demands. He wrote that after the SFC's electoral failure in 1945-46, little more could be done to help Dalits. He pointed out that Ambedkar could not argue to be the foremost representative of Dalits when even he had failed to be elected in Bombay. Thus, Attlee concluded, he would not change any of the decisions made by the Cabinet Mission. ${ }^{40}$ After Attlee's reply, Ambedkar realised that the political space for Dalits in an independent India was reducing dramatically. In consequence, he decided to take the fight straight to the Crown.

After being repeatedly snubbed by the colonial government in India, Ambedkar travelled to England in late 1946. Acknowledging the precarious position of the Dalit movement, he once again tried to bring international attention to untouchability. This made him look for the help of unlikely and disparate bodies such as the UN and the India Conciliation Group (ICG), and people like Jan Smuts and Winston Churchill. That Ambedkar approached such a variety of institutions and individuals highlights the tensions of his approach to politics. At the same time, it indicates that he was in a desperate situation because he was running out of options.

Ambedkar contacted Churchill—one of the main opponents of Attlee and the Cabinet Mission Plan -in the summer of 1946. Churchill's conservative, and on many occasions

\footnotetext{
${ }^{39}$ Ibid.

${ }^{40}$ Attlee to Ambedkar, 1 August 1946, in Vasant Moon (ed.), Dr. Babasaheb Ambedkar Writings and Speeches, Vol. 10 (New Delhi: Dr. Ambedkar Foundation, [1946] 2014),p. 509.
} 
actively harmful, attitude towards India is well known. ${ }^{41}$ He supported dominion status for India under two conditions; first, there was to be an agreement between the main political forces of the subcontinent; second, the rights of the rulers of the Princely States, Muslims and Dalits were to be constitutionally guaranteed. Churchill argued that the colonial government had the responsibility to "examine the provisions made for the depressed classes, or "untouchables" as they are called, who number 60 million, and for whose status and future repeated assurances have been given and pledge made by many British Governments'. ${ }^{42}$ While Churchill had his own selfish reasons for his statement, the last point regarding the rights of minorities caught Ambedkar's attention. He sent a telegram to Churchill on 17 May 1946 that accused the Cabinet Mission of a 'shameful betrayal' of the Dalit cause, claiming that since the Mission's proposals did not include any type of constitutional or electoral safeguards, the British were 'handing over untouchables bound hand and foot' to Hindus. ${ }^{43}$ He concluded by saying that Dalits would be grateful for Churchill's help.

Churchill acknowledged the cable promptly. He assured Ambedkar that the Conservative Party would do 'its utmost to protect the future of the sixty million Untouchables' in India. ${ }^{44}$ Churchill was aware that if his support for the Dalit cause was to amount to anything, it would need to gain the attention of the press. Thus he asked Ambedkar: 'shall I publish your message and my answer or will you?'45 The correspondence was duly published and the link between Churchill and Ambedkar garnered the press's interest.

\footnotetext{
${ }^{41}$ For instance Churchill refused to provide any type of relief during the Bengal famine of 1943 in which more than 2 million people died. See Madhusree Mukerjee, 'Winston Churchill's Plan for PostWar India', in Economic \& Political Weekly, Vol. 45 (2010), pp. 27-30.

${ }^{42}$ Twentieth Century House of Commons Hansard, Sessional Commons Sitting of Thursday, 16 May 1946, UK Parliamentary Papers [http://parlipapers.proquest.com/parlipapers/docview/t71.d76.cds5cv0422p0-0013?accountid=14664, accessed 5 November 2017].

${ }^{43}$ Ambedkar to Churchill, 17 May 1946, CHUR, Papers on India, CHUR 2/42A-B, f. 48, CHAR.

${ }^{44}$ Churchill to Ambedkar, 22 May 1946, CHUR, Papers on India, CHUR 2/42A-B, f. 45, CHAR.

${ }^{45}$ Churchill to Ambedkar, 25 May 1946, CHUR, Papers on India, CHUR 2/42A-B, f 42, CHAR.
} 
The conversations between Ambedkar and Churchill continued through the summer of 1946, peaking in the autumn. In late October Ambedkar travelled to England to personally explain to British politicians, including Churchill, the problems with the Cabinet Mission's proposals regarding Dalits. Ambedkar called in favours to reach the widest audience possible: important members of the Church community in England, with connections to India, were particularly interested in Ambedkar's trip. For instance, Reverend George S. Ingram from the Church Missionary Society secured an appointment for Ambedkar with Churchill. Rev. Ingram had met Ambedkar in the 1930s when the latter announced his intention to abandon Hinduism; Rev. Ingram had wanted to convert Ambedkar and Dalits to Christianity. Rev. Ingram's help in 1946 may have been another attempt to point Dalits towards the Christian fold ${ }^{46}$ To reach Churchill, Rev. Ingram contacted Col. Oliver Stanley, a close associate of Churchill's and the Conservative MP for Bristol West. ${ }^{47}$ On 25 October 1946, the Reverend wrote to Churchill advising him of Ambedkar's arrival in Britain, and asking for an interview in which he and Ambedkar would talk to Churchill about the 'political needs of the Depressed Classes in India' ${ }^{48}$ Churchill agreed and met Ambedkar at his country house in Kent in early November 1946.

The meeting between Ambedkar and Churchill was used to discuss their plan of action in relation to the Dalit cause. Churchill asked Ambedkar for a brief describing the main problems of the Cabinet Mission's proposals, intending to use the brief to object to Attlee's views during a parliamentary debate in December $1946 .{ }^{49}$ The other point of discussion was probably a revision of Ambedkar's planned statement to other British MPs. After meeting

\footnotetext{
${ }^{46}$ Indian Outcaste Movement arising from Dr Ambedkar's advice to Hindu 'outcastes' to Join Another Religion, December 1935, India General, General Secretary's Department, Church Missionary Society Archive, University of Birmingham, Birmingham.

${ }^{47}$ Oliver Stanley to Churchill, 22 October 1946, CHUR, Papers on India, CHUR 2/42A-B, f 251, CHAR.

${ }^{48}$ Ingram to Churchill, 25 October 1946, CHUR, Papers on India, CHUR 2/42A-B, f 250, CHAR.

${ }^{49}$ Ambedkar to Churchill, 20 November 1946, CHUR, Papers on India, CHUR 2/42A-B, f 268, CHAR.
} 
Churchill, Ambedkar gave a presentation to roughly twenty MPs. Richard Austen (Rab) Butler, a seasoned Conservative politician, witnessed the presentation and informed Churchill about the key developments. Butler noted that some Labour politicians and a few members of the Fabian Society had tried to prove to Ambedkar that 'he was not the only pebble on the Depressed Classes beach'. ${ }^{50}$ While Butler admitted that Ambedkar had had a 'grilling', he told Churchill that the meeting went without major incident and that Ambedkar had 'made a good impression on his critics'. ${ }^{51}$ Thus, by playing up the international importance of untouchability, Ambedkar was reaching influential spaces in England that had been previously closed to him.

Churchill and Ambedkar exchanged letters throughout 1947. While Churchill was happy to advance Ambedkar's demands in Britain, it is not certain how much faith he had in Ambedkar or his followers. For instance, just after Ambedkar's visit to London, Churchill received a letter from H.S. Lawrence, a former acting governor of Bombay. Lawrence complained to Churchill about Nehru's 'arrogance [in] threatening the British Army for suppressing the 1942 revolt'. On 23 November 1946, Lawrence wrote that Nehru had announced that he would 'prosecute officers and men, British and Indian who repressed the 1942 revolt in Bihar and East Bengal and restored the communication of the Army in Assam'. Lawrence considered that Nehru had gone too far and 'needs a lesson'. ${ }^{52} \mathrm{He}$ suggested to Churchill to use Dalits to retaliate against Congress. Lawrence claimed that he had been in touch with Ambedkar to advise him that 'Untouchables should protect themselves by the well-esteemed Labour device of withdrawing their services from all Caste Hindu houses'. The intention behind this was to cause Nehru to be 'hoist with his own petard'. However this

\footnotetext{
${ }^{50}$ Butler to Churchill, 20 November 1946, Public and Political: General: Political: Correspondence AB, CHUR 2/52A-B, f 39, CHAR.

${ }^{51}$ Ibid.

${ }^{52}$ H.S. Lawrence to Churchill, 25 November 1946, CHUR, Papers on India, CHUR 2/42A-B, f 348, CHAR.
} 
type of action was not straightforward. Lawrence explained to Churchill that Ambedkar's followers did not have the resources to put up a fight for an extended period of time. So Lawrence asked Churchill whether he could 'persuade firms interested in India to supply Ambedkar with a fighting fund'. Before making a decision, Churchill consulted Butler; although accepting that Nehru's statements were serious and that they 'should watch this matter', Butler advised Churchill against supporting Ambedkar:

I hardly think it would impress Mr. Nehru if Dr. Ambedkar were to issue this totally ineffective message to some hundreds of poor sweepers engaged in tending the dubious washrooms of caste Hindus.... Moreover, since alas the Scheduled Castes are divided up into various sections, other sweepers would hurry forward to earn their pies and annas. ${ }^{53}$

Churchill agreed with Butler. He decided not to support Lawrence or Ambedkar. Nevertheless Churchill kept raising the question of untouchability in the British parliament throughout the months prior to Indian independence. ${ }^{54}$ The link between Ambedkar and Churchill, while not very successful in the end, did bring international attention to the Dalit cause; more importantly, it pushed those closest to Gandhi into trying to persuade him to meet Ambedkar.

\section{The United Nations, the India Conciliation Group and Gandhi}

Ambedkar's visit to Britain also drew the attention of the Indian Conciliation Group, an organisation largely comprised of Quakers that had functioned as a broker between the British government and Congress. The leaders of the ICG, such as C.F. Andrews, Horace Alexander and Agatha Harrison, were very close to Gandhi. ${ }^{55}$ Untouchability had proved to be a difficult topic for the organisation to deal with: while it claimed that India deserved independence, the organisation's Christian values led it to condemn the treatment of Dalits

\footnotetext{
${ }^{53}$ Butler to Churchill, 3 December 1946, CHUR, Papers on India, CHUR 2/42A-B, f 341, CHAR.

${ }^{54}$ Churchill to Butler, 4 December 1946, CHUR, Papers on India, CHUR 2/42A-B, f 341, CHAR.

${ }^{55}$ See Geoffrey Carnall, Gandhi's Interpreter: A Life of Horace Alexander (Edinburgh: Edinburgh University Press, 2010).
} 
across India, leading to internal rifts between members. These internal differences flared up after Ambedkar's visit to Britain because part of the organisation feared the consequences of the relationship between Churchill and the Dalit leader.

The ICG's reservations about the Ambedkar-Churchill link can be seen in a letter from Agatha Harrison to Horace Alexander written on 26 November 1946. During her youth, Harrison had been involved in the fight for women worker's rights in Nottingham and Hull. After meeting Gandhi in the 1930s, she devoted most of her time to improving the relationship between India and Britain. For his part, Alexander was instrumental in securing Gandhi's attendance at the Round Table Conference of 1931, and he remained close to Gandhi for the rest of his life. Harrison's letter referred to Ambedkar's meeting with Churchill; she told Alexander: 'we [the ICG] have a job for you' ${ }^{56}$ The goal was to convince Ambedkar to negotiate with Congress. Harrison believed that Ambedkar's visit to Britain might prove hurtful to the Indian nationalist movement. Along with other members of the ICG, Harrison met Ambedkar in London in an effort to persuade him that untouchability was a 'matter that could only be settled in India' and 'not by getting disgruntled people strengthened in "What about the Untouchables"- that is increasing in volume of course helped by such a visit as this'. ${ }^{57}$

Harrison was particularly concerned with Ambedkar's attempts to internationalise untouchability and to claim a political space for it. She noticed that he was receiving attention from other members of the international community including Jan Smuts. Harrison was convinced that the Dalit cause would 'be used in the diehard circles' in Britain and elsewhere to advance their own goals. She warned Alexander that Smuts 'has used this lever (Dalits) at U.N.O' to impede the demands for the rights of Indians in South Africa.

\footnotetext{
${ }^{56}$ Harrison to Alexander, 26 November 1946, Correspondence, NMML.

${ }^{57}$ Ibid.
} 
Harrison was correct about Smuts. After the end of WWII, India became a member of the UN despite its status as a colony, giving it some freedom to decide on how to approach 'foreign politics' and even to refute international mandates. ${ }^{58}$ It is from this perspective that I continue my approach to Ambedkar's international politics. At the very first session of the UN, India presented a formal complaint about the discrimination suffered by Indian nationals in South Africa. ${ }^{59}$ Jan Smuts and his government were drafting South Africa's Asiatic Land Tenure and Indian Representation Act, ${ }^{60}$ also referred as the 'Ghetto Law', which was designed to restrict Indian property ownership in 'White areas' in Natal Province. Both the Indian National Congress and the Natal Indian Congress rejected the act. In protest, they took their case to the UN. The Indian representatives argued that the 'Ghetto Law' went against the spirit of the Preamble to the UN Charter of 1945 that was defended by Smuts himself. Furthermore Maharaj Singh, the Indian delegate to the UN and a former governor of Bombay, accused the South African government of racial discrimination. ${ }^{61}$

To these accusations Smuts replied that approval of the bill was a domestic matter over which the UN had no authority. Referring specifically to Singh's accusations of racial discrimination, Smuts argued that it was surprising that a country like India was complaining about inequality because inequality was 'the very basis and pattern of Indian society' ${ }^{62}$ To bolster his argument, Smuts brought up the problem of untouchability, which he described as a 'phenomenon unknown in South Africa and in the rest of the world'. He asked Singh whether he had 'forgotten the 50,000,000 depressed classes, with all the social ostracism and humiliation that they have to endure'. ${ }^{63}$

\footnotetext{
${ }^{58}$ Stephen Legg, 'An International Anomaly? Sovereignty, the League of Nations and India's Princely Geographies', in Journal of Historical Geography, Vol. 43 (2014), pp. 96-110.

${ }^{59}$ Saul Dubow, 'Smuts, the United Nations and the Rhetoric of Race and Rights', in Journal of Contemporary History, Vol. 43 (2008), pp. 45-74.

${ }^{60}$ The New York Times (24 June 1946; and 5 August 1947).

${ }^{61}$ The Manchester Guardian (14 November 1946).

${ }^{62}$ Ibid.

${ }^{63}$ Ibid.
} 
Ambedkar, who was already thinking about internationalising the Dalit cause, immediately identified the contradictions in India's appeal to the UN. India was fighting for the rights of the Indian minority in South Africa while refusing to recognise the struggle of Dalits at home. As a result, Ambedkar announced that his party would send a delegation to the UN to present the Dalits' grievances. As Harrison noted, Ambedkar's announcement was taken seriously due to Smuts' earlier comments. In the end, however, the alliance between Smuts and Ambedkar was not very successful. ${ }^{64}$ Ambedkar failed to find enough support within and outside the UN to present his case because the international system was more interested in Gandhi's fight for independence than untouchability. Nevertheless it should be emphasised that Ambedkar's conception of untouchability as an international problem did acquire some purchase, as Harrison noted in her letter to Alexander: 'Smuts, stupid (though clever) sidetracking of his own sore spot to the sore spot in India's body politic - has given the plight of these people (Dalits) a world hearing'. ${ }^{65}$ Before Ambedkar could find more allies, Harrison asked Alexander to intervene.

Harrison's plan was to get Gandhi and Ambedkar together. She thought that including Ambedkar in Congress' future would make it harder for him to protest. She told Alexander that maybe Ambedkar could 'be incorporated in some generous way' on the Advisory Committee on Minorities, which 'would be a disarming thing'. However, she also knew this would not be easy because Congress was 'fed up with being expected to do the "generous thing" and knowing that this man-maynt (sic) feel very cooperative'. Harrison did not have a very high opinion of Ambedkar, describing him as a 'bitter frustrated man — and rather lonely at that —and ambitious'. Nevertheless she acknowledged that he 'has an underlying case'. She trusted that in the end, Ambedkar's concern for Dalits would make him compromise with Congress. She thought this likely from Ambedkar's reaction to hearing Alexander's name. In

\footnotetext{
${ }^{65}$ Harrison to Alexander, 26 November 1946, Correspondence, NMML.
} 
her letter, Harrison told Alexander: 'I asked him if he knew you and his face lightened and he said "yes"...I told him I should be writing to you; that you were the kind of person who could bring people together quietly'. Her idea was to encourage Ambedkar to meet Gandhi because the former had made it clear that 'unless G. (Gandhi) made the move he could not'. Harrison concluded her letter by telling Alexander that the ICG was batting 'the ball over to you-to do what in your wisdom seems right'. ${ }^{66}$

Agatha Harrison was not the only member of the ICG to show concern about Ambedkar's activities abroad. Carl Heath, the famous pacifist behind the idea of establishing 'Quaker embassies' throughout the world, wrote to Gandhi directly to inform him about Ambedkar. On 14 November 1946 he told Gandhi that Ambedkar had met 'all manner of people' in London and that 'his attitude was very bitter, and the bitterness was largely directed at yourself and the Congress Governments'. Heath asked Gandhi if he could invite Ambedkar to see him as the latter 'will not seek such a meeting himself'. Heath was very sympathetic to Gandhi's views of untouchability as a 'deeply religious matter', but as he pointed out, Dalits 'can scarcely be expected to wait quietly for political redress until all those who oppress them are converted'. He asked Gandhi to try to 'accomplish political justice in this matter without breaking the moral and spiritual ties of the community of Hinduism'. If this did not happen, Heath feared that 'multitudes of men influenced by Dr Ambedkar should continue to nourish such bitterness of soul' ${ }^{67}$ In short, the letters of both Heath and Harrison show that Ambedkar's efforts to internationalise untouchability were having some impact, albeit limited, in Indian politics. The caveat to all of this was that Gandhi needed to accept meeting Ambedkar. But it was Gandhi who put an end to Ambedkar's efforts to internationalise untouchability.

\footnotetext{
${ }^{66}$ Ibid.

${ }^{67}$ Carl Heath to M.K. Gandhi, 14 November 1946. A copy of this letter was enclosed in Harrison to Alexander, 26 November 1946, Correspondence, NMML.
} 
Gandhi's reply to Heath came on 2 December 1946. The letter was concise: he was grateful for the efforts of the ICG but he would not meet Ambedkar. Gandhi claimed that while Ambedkar represented a good cause, he was 'a bad advocate for the simple reason that his passion has made him bitter and made him depart from the straight and narrow path'. Gandhi distrusted Ambedkar because 'with men like him the end justifies the means'. Gandhi also continued to criticise Ambedkar's book, What Congress and Gandhi Have Done to the Untouchables, which he believed was 'packed with untruths almost from beginning to end'. Gandhi told Heath: 'if I do not go out of my way to seek contact with Dr. Ambedkar it is not for want of will or want of regard for you and friends like you but because I know that such seeking will, in my view harm the cause [rather] than help it'. ${ }^{68}$

After Ambedkar announced his intention to take the plight of the Untouchables to the UN, various Congress leaders approached him, including Vallabhbhai Patel. In the summer of 1946, Patel and Ambedkar had a preliminary discussion at which Ambedkar asked for 20 percent of all types of electoral representation, and Patel promised to think about the demand. He later wrote to Gandhi for advice. On 1 August 1946, Gandhi replied that it was good that Patel had met with Ambedkar, but he cautioned Patel about the complications inherent in reaching an agreement with the Dalit leader. Gandhi claimed that Ambedkar should not be trusted because he made "no distinction between truth and untruth or between violence and non-violence'; moreover he had no principles, because he would 'adopt any means which will serve his purpose'. To illustrate this, Gandhi alluded to Ambedkar's understanding of religion as instrumental to politics, reminding Patel that 'one has to be very careful indeed when dealing with a man who would become a Christian, Muslim or Sikh and then be reconverted to his convenience'. Gandhi was convinced that Ambedkar's demands were 'all a

${ }^{68}$ Gandhi to Carl Heath, 2 December 1946, Pyarelal Papers, NMML. 
snare' or 'a "catch". ${ }^{69}$ Gandhi also wanted to maintain Congress' strategic position as a negotiator. He warned Patel: 'if we negotiate with Ambedkar out of fear of the League we are likely to lose on both fronts', because any type of pact agreed before independence would inevitably suffer alteration. However Gandhi did concede that the decision not to make an agreement with Ambedkar was also due to the attitude of Congress members towards Dalits. Gandhi told Patel: 'you may come up to any understanding you like today — but who are the people who beat up the Harijans, murder them, prevent them from using public wells, drive them out of schools and refuse them entry into their homes? They are Congressmen' ${ }^{70}$ As a result, Gandhi believed that reaching an agreement with Ambedkar was pointless. In contrast to the popular notion that Gandhi suggested to Nehru that Ambedkar should be brought into his new government, the paragraphs above suggest otherwise.

\section{Conclusion}

This article has explained Ambedkar's efforts to internationalise untouchability in the years prior to Partition. My intention is to rethink the scale in which the relationship between Partition and Dalit history may be studied. Throughout, I have shown that Ambedkar's move to the international was the result of what he saw as an eclipse of the Dalit political space in India; the Lahore Resolution had compromised the future of Dalit politics by virtually invalidating any possible political alliance that could compete against the Hindu majority. In order to prevent Dalits having to live in a perpetual 'Hindu Raj', Ambedkar tried to secure their rights before the British left India by pleading for international support in three different ways. First, he published a series of books and pamphlets written for a foreign audience, describing the Dalits' problems, and downplaying the importance of the concept of self-

\footnotetext{
${ }^{69}$ Gandhi to Patel, 1 August 1946, in The Collected Works of Mahatma Gandhi, Vol. 85 (New Delhi: Publications Division, Ministry of Information and Broadcasting, Government of India, [1946] 1982), p. 102.

${ }^{70} \mathrm{Ibid}$.
} 
determination by highlighting the primacy of minority rights over independence. Second, he sought the help of conservative politicians such as Churchill and Jan Smuts, to postpone the process of independence until some concessions had been made to Dalits. Finally, Ambedkar attempted to organise a Dalit delegation to present their grievances to the UN. The last two points show not only the ambivalent status of India in the international arena, but also the political spaces that Ambedkar imagined for Dalits beyond the subcontinent. While in the end, Ambedkar efforts to internationalise untouchability succumbed to the nationalist plans for independence, recovering these often-forgotten episodes remind us of the multiple histories that the subject of Partition still has to offer.

\section{Acknowledgements}

The completion of this article was possible due to an Early Career Research Fellowship funded by the Leverhulme Trust. This piece also benefitted from the invaluable comments of Stephen Legg, William Gould, Sunil Purushotham, Laura Loyola and two anonymous South Asia reviewers. All errors are mine. 